\title{
Performance evaluation of non-conventional constructions: Case study in a temperate climate
}

\author{
Pedro C.P. Silva ${ }^{\mathrm{a}, *}$, Manuela Almeida ${ }^{\mathrm{b}}$, Luís Bragança ${ }^{\mathrm{b}}$, Vasco Mesquita ${ }^{\mathrm{a}}$ \\ ${ }^{a}$ DST, S.A., Rua de Pitancinhos, Apartado 208, Palmeira, 4711-911 Braga, Portugal \\ ${ }^{\mathrm{b}}$ University of Minho, Civil Engineering Department, Campus de Azurém, 4800-058 Guimarães, Portugal
}

\section{A R T I C L E I N F O}

\section{Article history:}

Received 11 October 2011

Accepted 8 March 2012

Available online 20 March 2012

\section{Keywords:}

Energy performance

Sustainability

Non-conventional construction solutions

Test building

Model calibration

Simulation tools

\begin{abstract}
A B S T R A C T
The development of new construction solutions is fundamental to enhance the building stock energy performance, and thus promote sustainable development in the building sector. These solutions must be sensitive to both the energy performance and the environmental performance. The aim of the work presented in this paper is the energy performance evaluation of non-conventional envelope solutions that were applied in a test building built at the University of Minho's Azurém campus. The evaluation was carried out by means of data analysis of in situ measurements, and also the use of energy and daylighting simulation tools. Prior to the simulations it was necessary to calibrate the model and create a climatic data file representative of the real weather conditions. From this evaluation it was possible to assess the potentialities of different construction solutions. The non-conventional solution presented a similar energy performance but a better environmental performance than the conventional solution, due to the use of lower embodied energy materials. It was also proved that, with minor modifications, the non-conventional solution can produce a better energy performance than the conventional one, evidencing the potential of application of these solutions.
\end{abstract}

(c) 2012 Elsevier Ltd. All rights reserved.

\section{Introduction}

One of the most important challenges that modern civilization has to face is the problem of climatic changes and environmental degradation. Although it is not possible to pinpoint the individual responsible, it is well known that these challenges are closely related to the current excessive energy consumption and forms of obtaining it [1].

In the building sector, one of the main challenges is the higher thermal comfort requirements of the general population, which has led to an increase in the heating and cooling energy consumption. Nowadays the building sector in the EU is responsible for about $40 \%$ of the final energy consumption - of which $68 \%$ is due to residential buildings - and $1 / 3$ of the greenhouse gas emissions [2-4]. Thus, this is a very important sector when dealing with the achievement of sustainable development. Many different actions can be implemented in this sector to improve the energy efficiency of buildings, e.g. adopting more restrictive energy regulations [5-7], applying construction materials with less embodied energy, implementing

\footnotetext{
* Corresponding author. Tel.: +351 253510 200; fax: +351 253510217.

E-mail addresses: psilva@civil.uminho.pt (P.C.P. Silva), malmeida@ civil.uminho.pt (M. Almeida), braganca@civil.uminho.pt (L. Bragança), vasco.mesquita@dstsgps.com (V. Mesquita).
}

more effective construction solutions, take advantage of renewable energy sources, educating and raising the awareness of all the stakeholders [8-10].

In order to study and present low energy solutions for buildings in temperate climates, experimental test buildings were built at the University of Minho's Azurém campus, in Guimarães. According to Peel, Finlayson and McMahon [11], this region falls within the Köppen-Geiger climate classification of Temperate with dry and warm summer (Csb).

These experimental buildings are real scale buildings where several construction solutions can be tested. In light of the discussions on the advantages of Test Cell application in building thermal design [12], instead of following the conventional configuration applied in common Test Cells $[13,14]$, a decision was made to approximate the design of the test buildings to the typical design in use, so as to compare buildings with different envelope solutions but also different design options. One of those buildings was intended to be a Sustainable Test Building (Fig. 1 - STB), featuring an improved zoning pattern that combines a heavyweight zone and a lightweight zone, as well as an optimised wall/glazing ratio for the proposed orientation.

For a more precise evaluation of the solutions presented by the STB, a Conventional Test Building (Fig. 1 - CTB) was built using one of the most common Portuguese solutions, which consist in 


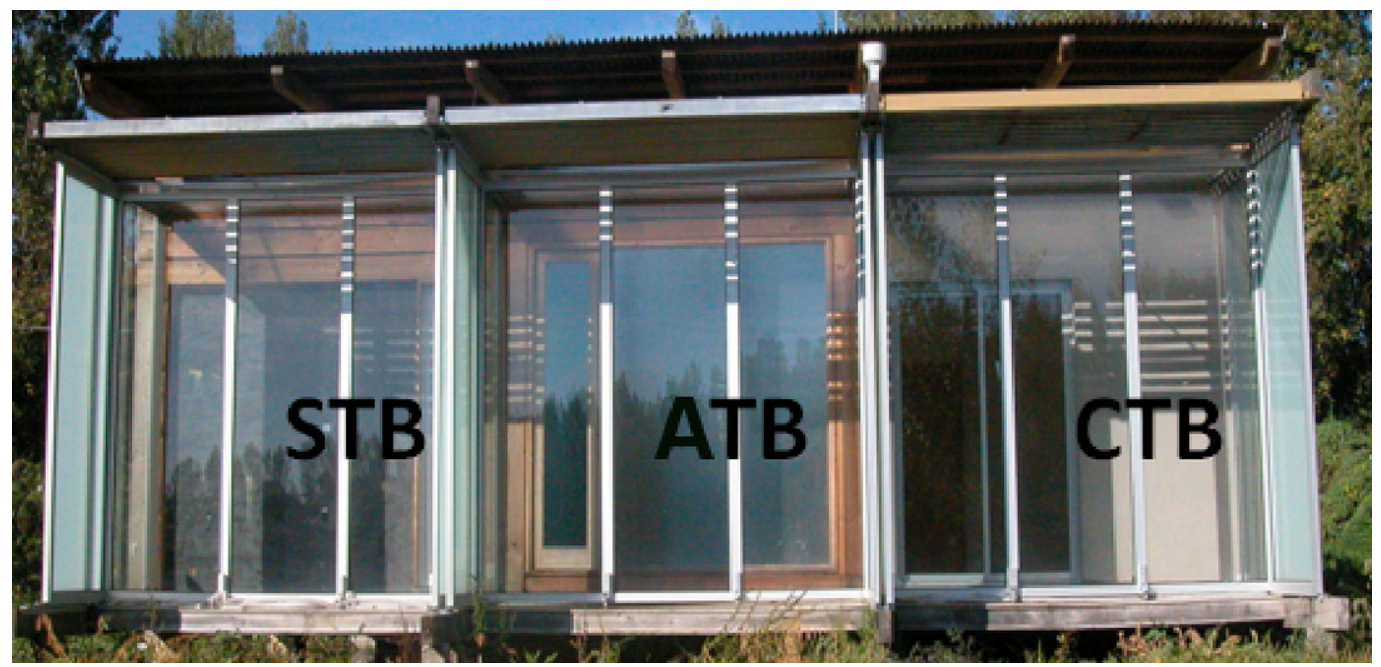

Fig. 1. Test building.

a heavyweight construction solution. Fig. 1 shows another test building, built with adiabatic walls (ATB). However, this test building was not used in this study.

The measurement system installed in the test buildings was based on the Passys project procedures in terms of type of sensors and related parameters to be monitored [15,16]. However, until this moment, it was not possible to install an HVAC system to measure the actual energy spent for heating and cooling the different test buildings.

The purpose of this study was the comparison of the thermal performance of the solutions implemented in the test buildings: the non-conventional solution, which is a mixed-weight construction with more environmentally friendly construction materials, and a conventional heavyweight construction solution. This study was carried out by means of in situ measurements, whose results were used to calibrate a building energy simulation model and a building daylighting simulation model. These results were further used to create a suitable weather file, which may be applied to later studies. With this study it was possible to fully compare the solutions implemented in the test buildings. In addition, this study will also enable us to conduct future studies with other innovative envelope solutions, which can range from simple solutions to others of great complexity [17], using the validated test buildings models.

\section{Case study - test buildings}

This study evaluates and compares the performance of two test buildings: the Sustainable Test Building (STB), a mixed-weight solution with low embodied energy materials and the Conventional Test Building (CTB), a heavyweight solution with high embodied energy materials. The characteristics and zoning patterns of the two test buildings are as described below:

- STB [Fig. 2a and c] - includes two rooms with different wall construction solutions.

$\bigcirc$ Room 1 simulates a bedroom. For this room, an indirect gain passive solar strategy was developed by creating a high thermal inertia space, taking advantage of the adobe masonry walls $(15 \mathrm{~cm})$ on the south-facing exterior envelope [18], together with a well-placed south-oriented opening, equipped with overhangs and fins, and a west facing adobe masonry wall $(15 \mathrm{~cm})$ with an air gap $(4 \mathrm{~cm})$, agglomerated cork insulation $(5 \mathrm{~cm})$ and an agglomerated wood cement board finishing $(1.2 \mathrm{~cm})$. This type of wall was chosen in order to improve the sustainability of the solution as adobe and cork have low embodied energy and are locally available materials.

Room 2 simulates an office. It is a lightweight construction consisting of a triple wall with plasterboard interior finishing $(1.3 \mathrm{~cm})$, coconut fibre insulation $(2 \mathrm{~cm})$, agglomerated cork insulation, agglomerated wood cement board $(1.9 \mathrm{~cm})$, an air gap $(6 \mathrm{~cm})$ and agglomerated wood cement board finishing $(1.2 \mathrm{~cm})$, as well as a large opening in the north façade in order to promote the daylighting and thus reduce the lighting energy consumption.

$\bigcirc$ Hollow core slabs, with $30 \mathrm{~cm}$ and $20 \mathrm{~cm}$, respectively, were used for the STB floor and roof on the south zone (heavy zone). The structure has a lightweight roofwith coconut fibre insulation $(2 \mathrm{~cm})$ and agglomerated cork insulation $(8 \mathrm{~cm})$ between two agglomerated wood cement boards $(1.9 \mathrm{~cm}$ on the bottom and $1.2 \mathrm{~cm}$ on the top); and a lightweight floor with agglomerated wood cement board $(1.9 \mathrm{~cm})$ and coconut fibre insulation $(2 \mathrm{~cm})$. The floor is supported by a wood structure, and it features an air gap $(10 \mathrm{~cm})$, agglomerated cork insulation $(8 \mathrm{~cm})$, as well as agglomerated wood cement board $(1.2 \mathrm{~cm})$ on the north zone (light zone);

- CTB [Fig. 2b and c] - contains three rooms with similar construction solutions.

$\bigcirc$ Room 1 simulates a bedroom; Room 2 simulates a bathroom; Room 3 simulates a hall;

The CTB exterior envelope is a double pane hollow brick masonry $(15 \mathrm{~cm}+11 \mathrm{~cm})$ wall with extruded polystyrene insulation $(4 \mathrm{~cm})$ in the air gap $(4 \mathrm{~cm})$, plaster exterior and interior finishing $(2 \mathrm{~cm})$;

$\bigcirc$ CTB has a massive concrete structure, with floor and ceiling on pre-stressed concrete "T" beams and hollow brick, and extruded polystyrene insulation $(4 \mathrm{~cm})$;

$\bigcirc$ This test building represents the conventional Portuguese Construction system [19-21].

Also, all the test buildings were equipped with sunspaces so as to promote indirect solar gains [Figs. 1 and 2a,b and c].

\subsection{Measurement system}

In order to evaluate the thermal performance of the test buildings, as well as to provide data for the evaluation of the chosen 

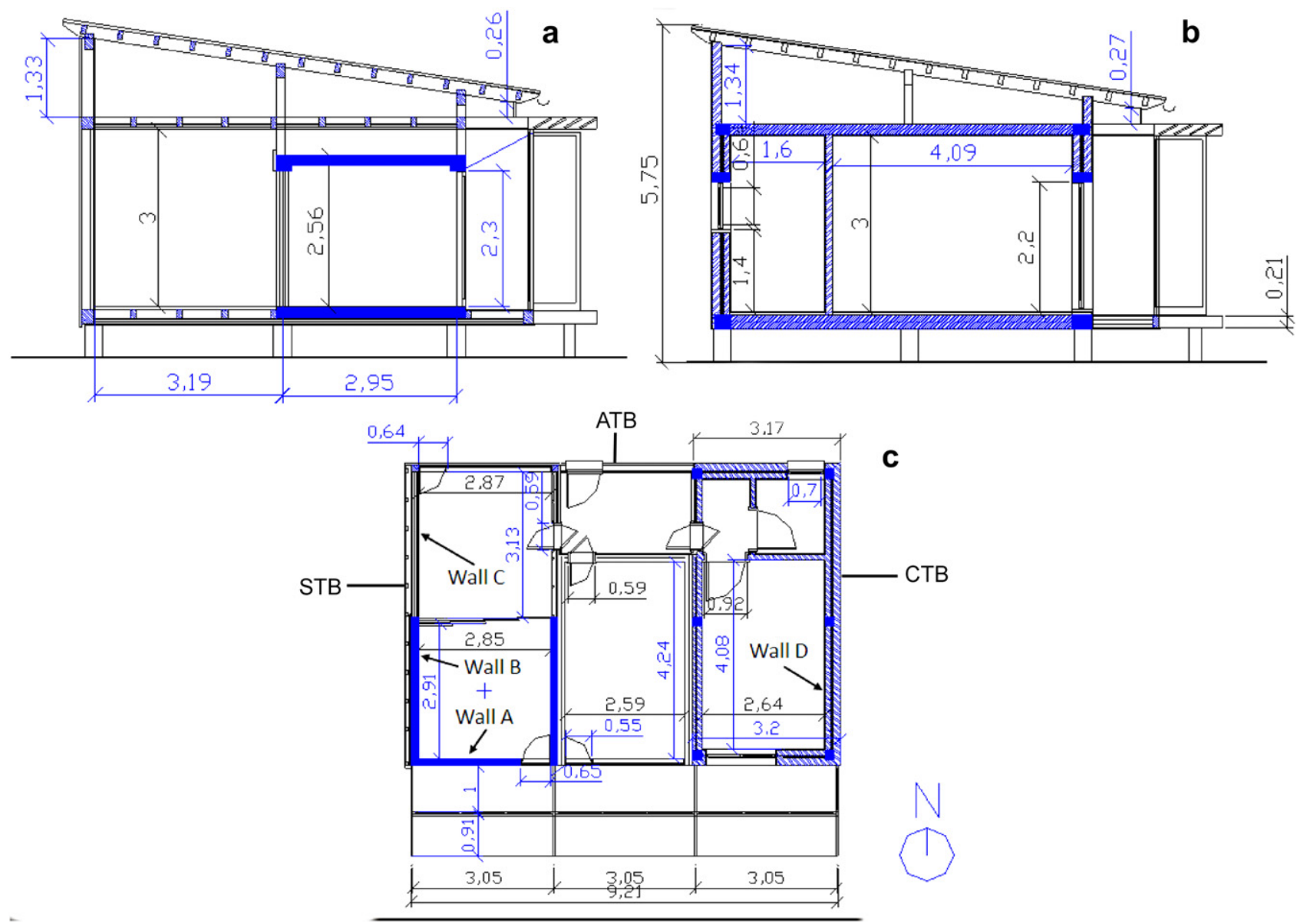

Fig. 2. a) STB: lateral cross-section; b) CTB lateral cross-section; c) Test buildings floor plans (dimensions in metres).

solutions, a measurement system was installed. This measurement system is divided in three base components:

1) Weather station: air temperature and relative humidity sensor; wind speed and direction sensor; solar radiation sensor; precipitation sensor;

2) Measurement system of the test buildings: three interior temperature sensors; four interior air temperature and relative humidity sensors; 37 surface temperature sensors (thermocouples) distributed among the inner and outer surface of the walls and glazings of the test buildings; four heat flux sensors; two lux meter sensors; two air flow sensors;

3) Data acquisition system - this component contains a data logger with two multiplexers and a supporting computer.

Additionally, a blower door was used once per month during the measurement campaign in order to measure the infiltration rate of the Test Buildings.

\section{Methodology for performance evaluation}

The performance assessment of the test buildings was based on in situ measurements, and simulations were carried out with VisualDOE 3.1 [22] and Desktop Radiance 2.0 BETA [23] tools. The model applied to simulate the test buildings was calibrated with experimental data. The experimental data further allowed for the verification of the proposed model accuracy.

During this study, two test building configurations were assessed in order to evaluate the added value to the performance of an indirect gain passive solar strategy without attached sunspace; and with south façade-attached sunspace. Subsequently, the models representing both configurations were generated (Fig. 3).

\subsection{Model calibration}

To guarantee good accuracy of the model, a calibration was performed in order to adjust the model to the reality:

- Obtain weather file representative of the climatic conditions to which the test buildings were exposed during this study;

- Obtain the in situ thermal resistance of exterior walls;

- Compare the interior temperature measured in situ with the one simulated.

\subsubsection{Weather file}

Nowadays, in Portugal, the use of simulation tools is mandatory for all new office buildings. For that reason, there is a high demand for methodologies to create weather files for cities that are not referenced in most current simulation tools.

For this case study, a weather file was created by means of the data retrieved from the weather station installed in the test buildings [24]. However, in addition to the parameters directly obtained from the weather station, the calculation of additional parameters was required (underlined in Table 1) [25-27]:

In order to systematise and support the creation of other weather files, the equations applied to calculate the required parameters are presented in Eqs (1)-(16): 


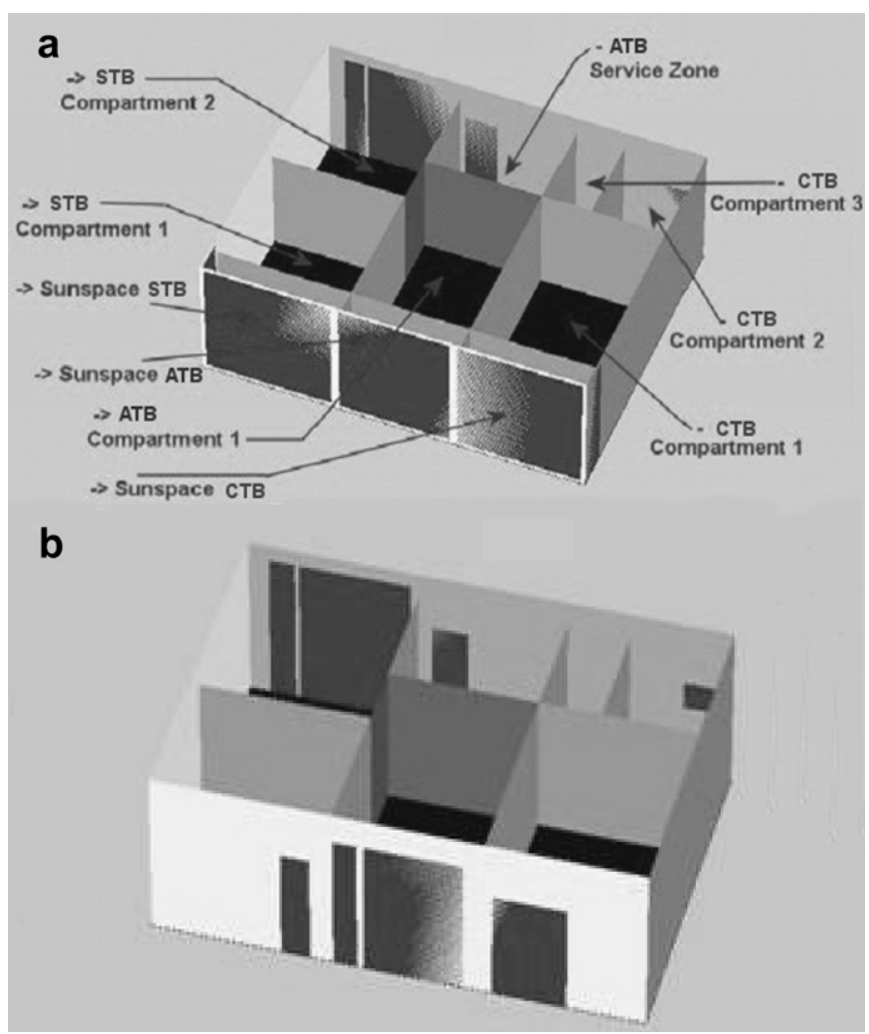

Fig. 3. Model of the test buildings: a) With sunspace, b) without sunspace.

Humidity Ratio $(W)$ :

$W=0.62198 \cdot \frac{P v}{100.332-P v}$,

$P v=P s \cdot \frac{R H}{100}$

$P S=\frac{610.5 \cdot e^{\left(17.26 \cdot T_{\mathrm{ext}}\right) /\left(T_{\mathrm{ext}}+237.3\right)}}{1000}$

Where: Ps - saturation pressure (kPa); $P v$ - vapour pressure $(\mathrm{kPa})$; $R H$ - relative humidity (\%); $T_{\text {ext }}$ - exterior temperature $\left({ }^{\circ} \mathrm{C}\right)$.

Wet bulb Temperature $\left(T_{W B}\right)$ - for this parameter, Newton's iterative method was employed as the equations applied to calculate this parameter were nonlinear:

Table 1

Simulation tool required climatic data.

\begin{tabular}{lll}
\hline In Situ parameters & Required parameters & Obtained from: \\
\hline 1) Temperature & Dry bulb Temperature & $1)$ \\
2) Relative Humidity & Wet bulb Temperature & $1) ; 2)$ \\
3) Precipitation & Humidity Ratio & $1 ; 2)$ \\
4) Wind Direction & Enthalpy & $1) ; 2)$ \\
5) Wind Speed & Precipitation & $3)$ \\
& Wind Direction & $4)$ \\
6) Total Horizontal & Wind Speed & $5)$ \\
Solar Radiation & Total Horizontal & $6)$ \\
& Solar Radiation & \\
& Solar radiation on & $6)$ \\
& a horizontal surface & $6)$ \\
\hline
\end{tabular}

$T_{\mathrm{WB}}=\frac{W \cdot\left(2501+1.805 \cdot T_{\mathrm{ext}}\right)-2501 \cdot W^{*} s+T_{\mathrm{ext}}}{1-2.381 \cdot W^{*} s+4.186 \cdot W}$.

Where: $W^{*} s$ - humidity ratio at the wet bulb temperature. Enthalpy $(E)$ :

$E=1.006 \cdot T_{\text {ext2 }}+\left(2501+1.84 \cdot T_{\text {ext } 2}\right) \cdot W$.

Where: $\mathrm{E}$ - enthalpy ( $\mathrm{kJ} / \mathrm{kg}) ; T_{\text {ext } 2}$ - exterior temperature $\left({ }^{\circ} \mathrm{C}\right)$

Solar radiation on a horizontal surface $\left(I_{d i s_{-} N}\right)$ :

$\delta=a \sin \cdot\left(-\sin 23.45 \cdot \cos \left(\frac{360 \cdot(d+10)}{365.25}\right)\right)$,

$B=360 \cdot \frac{d-81}{364}$,

$E t=9.87 \cdot \sin (2 B)-7.53 \cdot \cos (B)-1.5 \cdot \sin (B)$,

$H=\frac{\left(T_{\mathrm{SUN}}-12\right) \cdot 360}{24}$

$\theta_{\mathrm{S}}=a \cos \cdot(\cos (\lambda) \cdot \cos (\delta) \cdot \cos (H)+\sin (\lambda) \cdot \sin (\delta))$,

$T_{\mathrm{SUN}}=T_{\mathrm{Loc}}+\frac{E t}{60}+\frac{\lambda}{15}$

$I_{0}=\left(1+0.033 \cdot \cos \frac{360 \cdot d}{365.25}\right) \cdot 1373$

$K_{\mathrm{T}}=\frac{I_{\text {glo }}}{I_{0} \cdot \cos \theta_{S}}$,

$I_{\text {dif } \_\mathrm{H}}=\left\{\begin{array}{l}I_{\text {glo }} \cdot\left(1-0.249 \cdot K_{\mathrm{T}}\right) \rightarrow 0 \leq K_{\mathrm{T}} \leq 0.35 \\ I_{\text {glo }} \cdot\left(1.557-1.84 \cdot K_{\mathrm{T}}\right) \rightarrow 0.35 \leq K_{\mathrm{T}} \leq 0.75 \\ I_{\text {glo }} \cdot 0.177 \rightarrow K_{\mathrm{T}} \geq 0.75\end{array}\right.$

$I_{\text {dir_H }}=I_{\text {glo }}-I_{\text {dif_H }_{-}}$

$I_{\text {dis_N }}=\frac{I_{\text {dir_H }}}{\sin (\theta)}$.

Where: $\delta$-solar declination $\left({ }^{\circ}\right)$; $d$-day of the year (day); $B$-day of the year $\left({ }^{\circ}\right)$; Et-time equation (min); $H$-solar height $\left({ }^{\circ}\right) ; T_{S U N}$-solar time

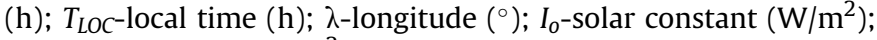
$K_{T}$-Clarity index $\left(\mathrm{W} / \mathrm{m}^{2}\right)$; $I_{g l o}$-total horizontal solar radiation $\left(\mathrm{W} / \mathrm{m}^{2}\right) ; I_{\text {dif } H_{-}}$-diffuse horizontal solar radiation $\left(\mathrm{W} / \mathrm{m}^{2}\right) ; I_{\text {dir_ }} H^{-}$-direct horizontal solar radiation $\left(\mathrm{W} / \mathrm{m}^{2}\right)$.

With all the necessary parameters calculated, a Microsoft ${ }^{\circledR}$ excel worksheet was created containing a whole year's climatic data. Using correct column organisation and spacing, the climatic data was introduced in the Weather File Converter provided by the simulation tool, and a weather file suitable for this simulation tool was thus obtained.

\subsubsection{In situ thermal resistance}

The in situ thermal resistances of the exterior walls of the test buildings were obtained by applying the ASTM Sum Technique from the Standard C1155-95 [28]. This method requires the measurement of the heat flux and both interior and exterior surface temperatures of all the envelope elements. Afterwards, the thermal resistance $\left(R_{e}\right)$ for a time interval of $672 \mathrm{~h}$ was obtained with the help of Eq. (17): 
Table 2

Test buildings exterior walls thermal resistance.

\begin{tabular}{|c|c|c|c|c|c|c|c|}
\hline \multirow[t]{2}{*}{ Wall } & \multicolumn{6}{|c|}{ Construction elements (outside to inside) } & \multirow{2}{*}{$\begin{array}{l}\text { Thermal resistance } \\
\mathrm{m}^{2}{ }^{\circ} \mathrm{C} / \mathrm{W}\end{array}$} \\
\hline & Element 1 & Element 2 & Element 3 & Element 4 & Element 5 & Element 6 & \\
\hline $\bar{A}$ & Adobe, $15 \mathrm{~cm}$ & - & - & - & - & - & $0.34 \pm 0.031$ \\
\hline B & $\begin{array}{l}\text { Agglomerated } \\
\text { board, } 1.2 \mathrm{~cm}\end{array}$ & Air gap, $4 \mathrm{~cm}$ & $\begin{array}{l}\text { Expanded cork } \\
\text { insulation, } 5 \mathrm{~cm}\end{array}$ & Adobe, $15 \mathrm{~cm}$ & - & - & $2.97 \pm 0.282$ \\
\hline C & $\begin{array}{l}\text { Agglomerated } \\
\text { board, } 1.2 \mathrm{~cm}\end{array}$ & Air gap, $6 \mathrm{~cm}$ & $\begin{array}{l}\text { Agglomerated } \\
\text { board, } 1.9 \mathrm{~cm}\end{array}$ & $\begin{array}{l}\text { Agglomerated } \\
\text { cork insulation, } 8 \mathrm{~cm}\end{array}$ & $\begin{array}{l}\text { Coconut fibre } \\
\text { insulation, } 2 \mathrm{~cm}\end{array}$ & plasterboard, $1.3 \mathrm{~cm}$ & $1.04 \pm 0.089$ \\
\hline $\mathrm{D}$ & Plaster, 2 cm & Hollow brick, $11 \mathrm{~cm}$ & Air gap, $4 \mathrm{~cm}$ & $\mathrm{XPS}, 4 \mathrm{~cm}$ & $\begin{array}{l}\text { Hollow brick, } \\
15 \mathrm{~cm}\end{array}$ & Plaster, $2 \mathrm{~cm}$ & $2.20 \pm 0.153$ \\
\hline
\end{tabular}

$R_{\mathrm{e}}=\frac{\sum_{k=1}^{M}\left(T_{\mathrm{isk}}-T_{\mathrm{esk}}\right)}{\sum_{k=1}^{M} q_{\mathrm{ik}}}$

Where: $\mathrm{q}_{\mathrm{i}}$ heat flux $\left(\mathrm{W} / \mathrm{m}^{2}\right), T_{i s}$ interior surface temperature $\left({ }^{\circ} \mathrm{C}\right), T_{e s}$ exterior surface temperature $\left({ }^{\circ} \mathrm{C}\right), M$ time interval of the thermal resistance measurement period $(h)$.

The performance of convergence $(C R)$ and variance $(V)$ tests was necessary to guarantee the integrity of the data applied to calculate wall thermal resistance, as shown in Eqs. (18) and (19):

$C R_{\mathrm{n}}=\frac{R_{\mathrm{e}}(t)-R_{\mathrm{e}}(t-n)}{R_{\mathrm{e}}(t)}$

$V\left(R_{\mathrm{e}}\right)=\left[\mathrm{S}\left(R_{\mathrm{e}}\right) / \operatorname{Mean}\left(R_{\mathrm{e}}\right)\right]^{*} 100$

Where: $t$ time interval of convergence test $(h)$

$n$ time lag interval $(\mathrm{h})$

The time lag applied for the convergence test was $12 \mathrm{~h}$. Furthermore, the confidence interval of the results was obtained by applying the equipment errors to all the measured data, and subsequently calculating for each measurement the maximum and minimum value (accuracy of the heat flux meter, $\pm 20 \%$ of daily totals; calibration of the thermocouples, $\pm 0.5^{\circ} \mathrm{C}$ ). The thermal resistances of the envelope elements [according to Fig. 2c] are shown in Table 2, and include the interior surface thermal resistances.

\subsubsection{In situ temperature vs. simulated temperature}

The comparison of the in situ temperatures with the simulated temperatures was very useful for the model error-checking and last adjustments, allowing for the detection of any inaccuracy in the model. With this course of action, it was possible to:

- Detect an error on thermal inertia defined in the simulation tool, due to an inaccurate material density input (there was a switch from commas to dots);

- Resolve the problem of sunspaces, which did not present the expected results. This was solved by manually adding the command line "SUNSPACE = YES" on the DOE2.1 input file, since VisualDOE was not able to define a space as a sunspace [29];

- Achieve an increase of the model accuracy by applying the measured thermal resistances and infiltrations.

In Fig. 4, it is possible to check the performance of the model before and after the adjustments. The average error of the model without sunspace is $8 \%$, and the error for the model with sunspace is $4.8 \%$.

\subsection{In situ performance}

As this study intends to evaluate the thermal performance of the test building, the indoor air temperature and the relative humidity are key parameters. However, ASHRAE [25] indicates that the resultant temperature $\left(T_{r}\right)$ should be applied to evaluate the thermal comfort, which is obtained as an average of the indoor air temperature and the mean radiant temperatures, as shown in Eqs. (20) and (21):

$$
\begin{aligned}
& T_{\mathrm{r}}=\frac{\alpha_{\mathrm{r}} \times \overline{T_{\mathrm{s}}}+\alpha_{\mathrm{c}} \times T_{\mathrm{a}}}{\alpha_{\mathrm{r}}+\alpha_{\mathrm{c}}} \\
& \overline{T_{\mathrm{S}}}=\sum_{i=1}^{n} T_{i} \times F_{p i}
\end{aligned}
$$

Where: $\alpha_{r}$ radiant coefficient, $\alpha_{c}$ convection coefficient, $T_{a}$ indoor air temperature $\left({ }^{\circ} \mathrm{C}\right), T_{S}$ mean radiant temperature $\left({ }^{\circ} \mathrm{C}\right), T_{i}$ inside surface temperature $\left({ }^{\circ} \mathrm{C}\right)$

$F_{p i}$ angle factor
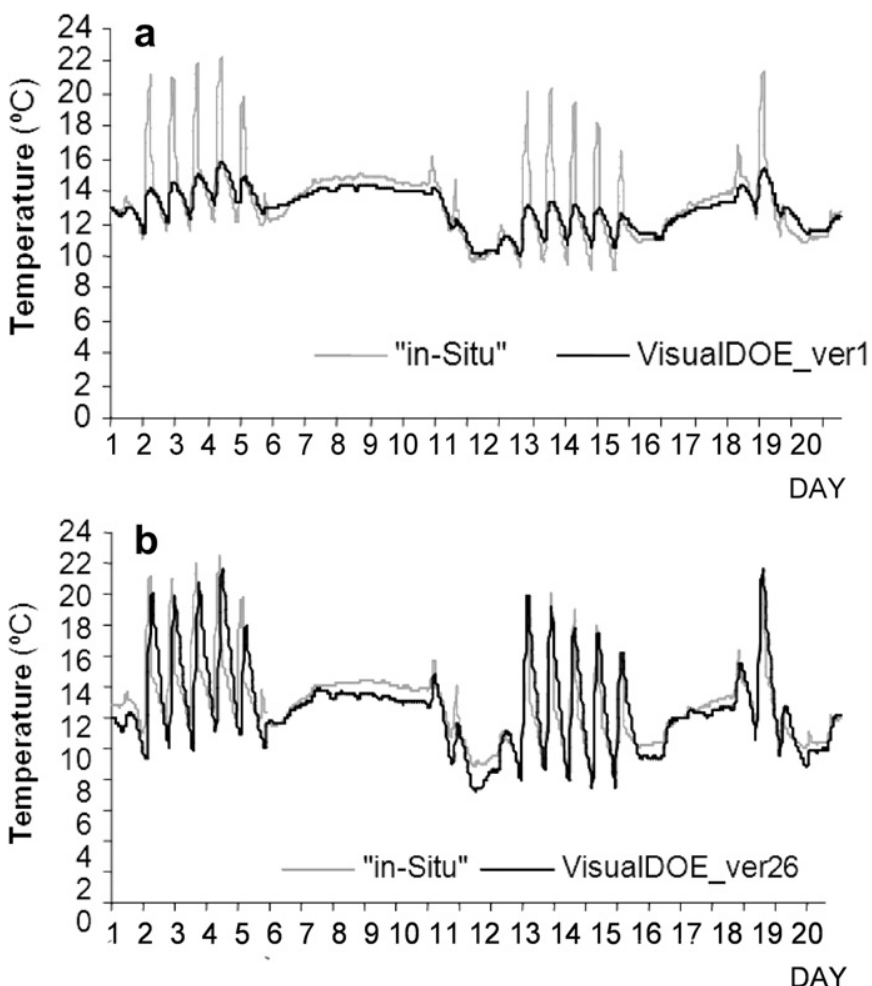

Fig. 4. Graph of СТВ simulated interior temperature: a) before model calibration, b) after model calibration. 


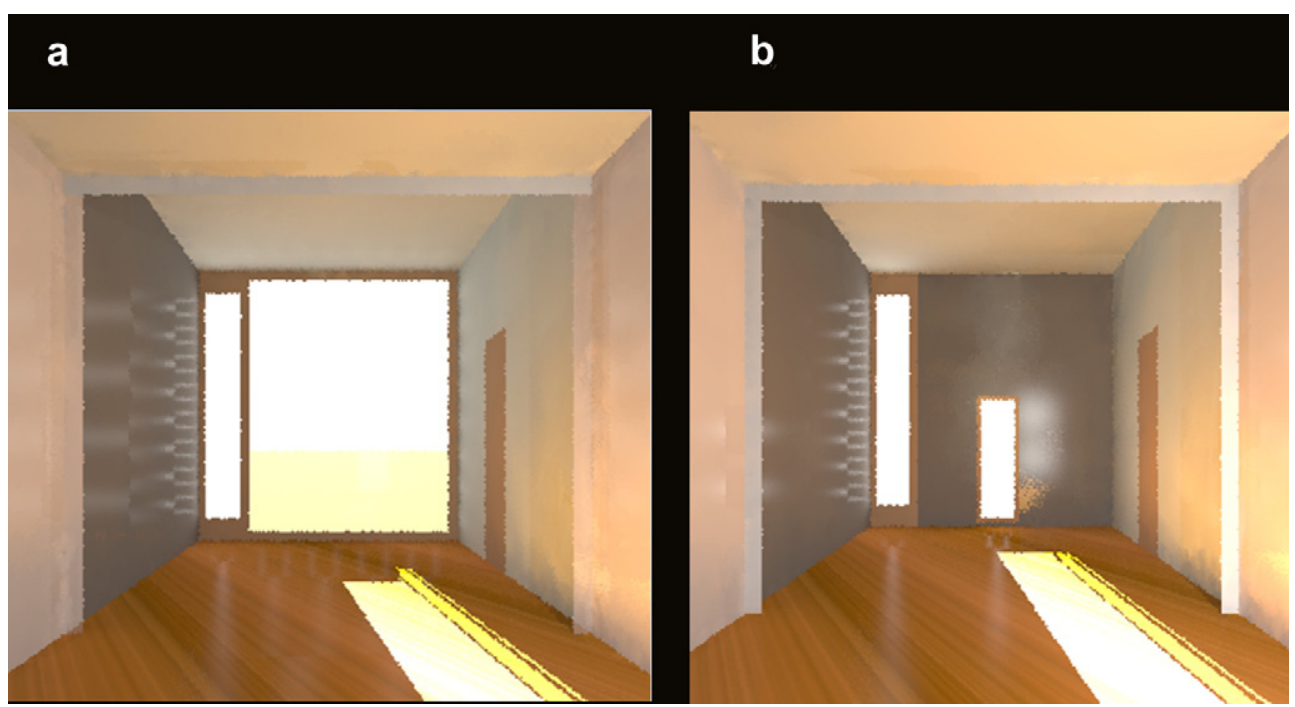

Fig. 5. STB natural illumination simulation tool model: a) original b) reduced glazing.

The angle factor $\left(F_{p i}\right)$ can be obtained using the charts produced by Fanger [30] that take into account the occupant's position and orientation inside the room.

The thermal comfort evaluation was then based on the comparative study of the relative humidity and resultant temperature in the СTB and the STB, provided by a whole year's data obtained from the installed measurement system.

\subsection{Energy simulation}

To perform a more extended evaluation, a dynamic energy simulation tool was applied.

Additionally, the simulation tool allowed us to study the necessary modifications in the STB to enhance energy efficiency: improvement of the north façade characteristics of this test building, i.e. the reduction of the window area and the replacement of the glazing by another one with better properties.

In order to study the test building energy performance with the simulation tool, two models of the test buildings were applied, featuring an HVAC system with a heating setpoint of $20{ }^{\circ} \mathrm{C}$ and a cooling setpoint of $25{ }^{\circ} \mathrm{C}$, as recommended by the Portuguese Buildings Thermal Regulation. The occupation, illumination and equipment schedules also represent the typical Portuguese residential buildings.

\subsection{Daylighting simulation}

Since the alternative design for the STB implies the reduction of the glazed area on the north façade, a daylighting tool was applied to estimate the daylighting performance of the test building alternative design.

A portable lux meter was used to verify the accuracy of the simulation model. The measurements were always performed under cloudy skies, over a net of points spaced by $0.5 \mathrm{~m}$ on a horizontal plane located $0.76 \mathrm{~m}$ above the ground [31,32], and also on some specific days - summer and winter solstice and spring and autumn equinoxes.

Two models of the STB were created, one with the original solution [Fig. 5a] and another with a smaller glazing area on the north façade [Fig. 5b)].

The measured illuminances were compared with the ones simulated for the original solution, and an average error of $7 \%$ was obtained for the simulation.

\section{Results \& discussion}

\subsection{In situ evaluation}

To assist with the evaluation of the extensive data measured over the year in the CTB and STB concerning relative humidity and resultant temperature, several graphs were elaborated, such as those presented in Fig. 6 and Fig. 7.

Also, with the application of the blower door, once per month, the measured average air changes rates of the CTB were 0.95 ach, whereas those of the STB were 1.03 ach.
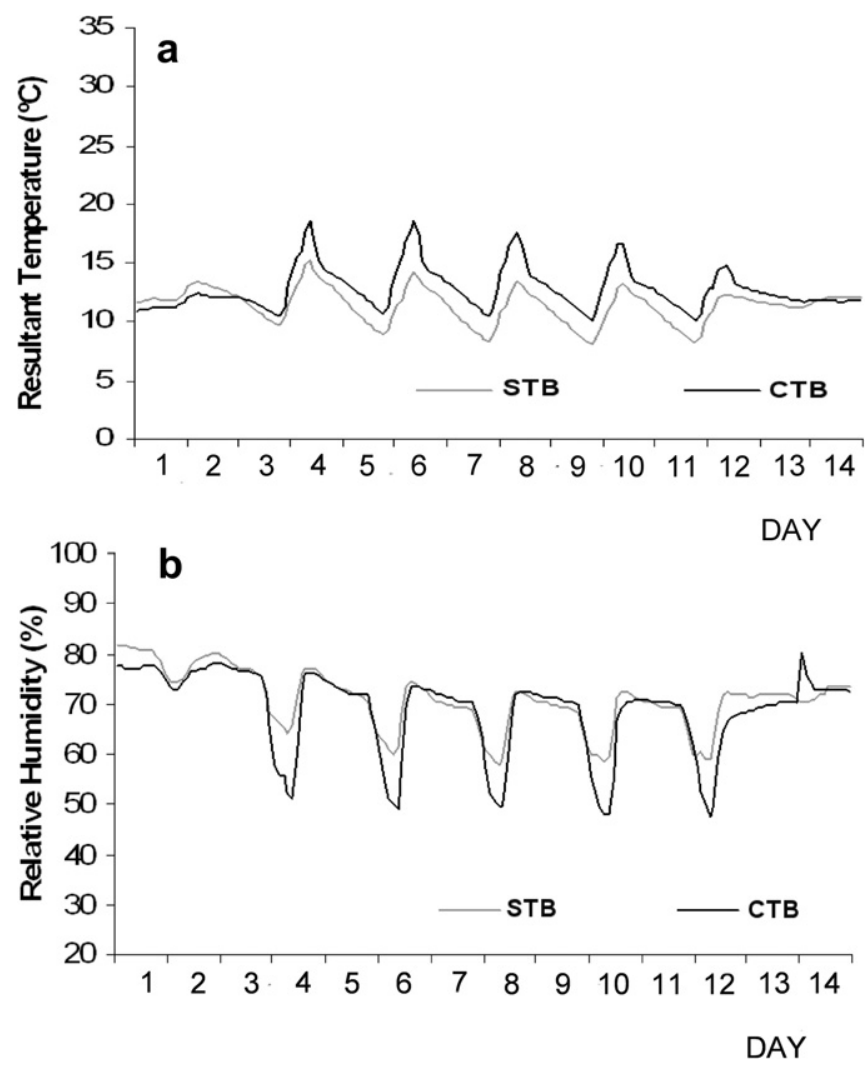

Fig. 6. Test buildings measured data for a winter period - from November 12 to 16 : a) Resultant temperature, b) Relative humidity. 

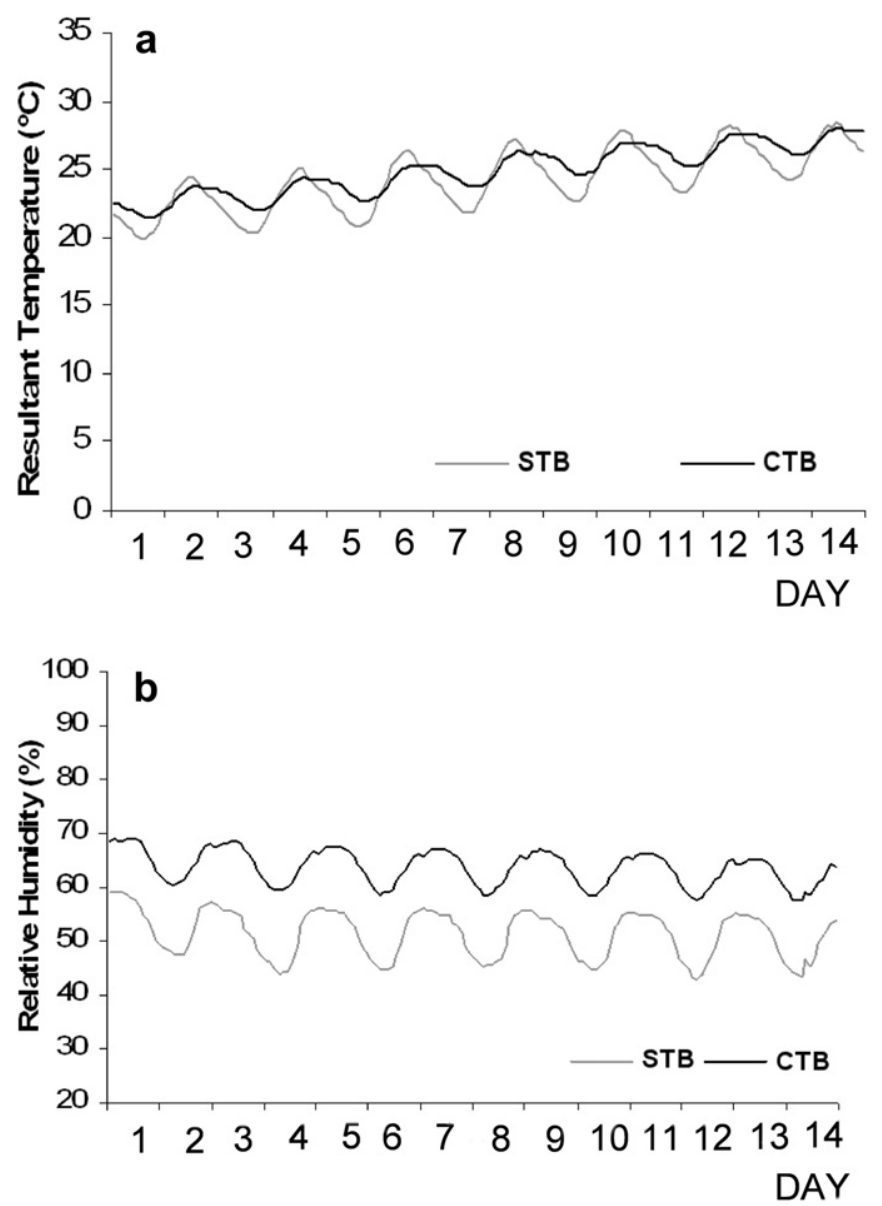

Fig. 7. Test buildings measured data for a summer period - from may 14 to 20: a) Resultant temperature, b) Relative humidity.

From the in situ evaluation it was verified that:

- For the summer period, the CTB has a better thermal performance, with a lower maximum temperature but with a higher relative humidity (in summer a high relative humidity can be a discomfort factor due to increased difficulty in skin perspiration);

- In the winter period, the CTB has a slightly better performance, mostly due to the wider glazing area on the south façade of this test building, but again it presents a higher relative humidity, which in some points exceeded the ASHRAE recommended values;

- Since the infiltration rate of the STB is higher and the adobe masonry walls have a better hygroscopic performance, with a higher balancing effect, this test building has a lower relative humidity than the CTB.

Table 3

Energy consumption for the STB and the CTB.

\begin{tabular}{llrrrr}
\hline \multirow{2}{*}{ Energy consumption $\left(\mathrm{kWh} / \mathrm{m}^{2}\right.$.year $)$} & \multicolumn{2}{l}{ STB } & \multirow{2}{*}{ CTB } \\
\cline { 3 - 5 } & & Room 1 & Room 2 & Total & \\
\hline With sunspace & Heating & 73.3 & 187.9 & 130.7 & 126.8 \\
& Cooling & 15.7 & 81.9 & 48.8 & 15.1 \\
\multirow{2}{*}{ Without sunspace } & Total & 89.0 & 269.8 & 179.5 & 141.9 \\
& Heating & 103.6 & 186.9 & 141.7 & 158.2 \\
& Cooling & 23.8 & 83.7 & 48.9 & 37.1 \\
& Total & 127.4 & 270.6 & 199.0 & 195.4 \\
\hline
\end{tabular}

Table 4

Energy consumption for the STB after the modifications.

\begin{tabular}{llrrrr}
\hline \multirow{2}{*}{ Energy consumption $\left(\mathrm{kWh} / \mathrm{m}^{2}\right.$.year $)$} & \multicolumn{2}{l}{ STB } & \multirow{2}{*}{ CTB } \\
\cline { 3 - 5 } & & Room 1 & Room 2 & Total & \\
\hline With sunspace & Heating & 126.8 & 129.7 & 102.1 & 126.8 \\
& Cooling & 15.1 & 36.9 & 26.6 & 15.1 \\
\multirow{2}{*}{ Without sunspace } & Total & 141.9 & 166.7 & 128.7 & 141.9 \\
& Heating & 158.2 & 129.1 & 118.3 & 158.2 \\
& Cooling & 37.1 & 37.7 & 31.3 & 37.1 \\
& Total & 195.4 & 166.8 & 149.6 & 195.4 \\
\hline
\end{tabular}

\subsection{Energy simulation}

The energy performance assessment of both test buildings STB (room 1 and 2) and CTB - was conducted throughout a whole year by means of a dynamic energy simulation tool. The results presented in Table 3 indicate that the CTB is $21 \%$ and $2 \%$ more energy efficient than the STB considering the test buildings with and without sunspace, respectively. However, the STB uses solutions with lower embodied energy. Also, when analysed separately, STB room 1 always presents the best energy performance, since room 2 was designed to maximise daylight performance due to a large window area on the north façade, which reduced its thermal performance. Nonetheless, for the case without sunspace, the difference is insignificant but with the advantage of the STB presenting a better performance for the heating season.

To improve the performance of STB room 2, the opening on the north façade was reduced from $4.32 \mathrm{~m}^{2}(2.4 \times 1.8 \mathrm{~m})$ to $0.56 \mathrm{~m}^{2}$ $(1.4 \times 0.4 \mathrm{~m})$, and the initial polycarbonate sheet was replaced by double glass. The results obtained from the energy simulation of the modified STB (Table 4 and Fig. 8) indicate that with these modifications the STB is now $9 \%$ and $23 \%$ more energy efficient than the CTB considering the test buildings with and without sunspace, respectively.

Also, the energy simulation evaluation showed that the indirect gain passive solar strategy derived from the addition of sunspace enhanced the energy performance of both test buildings.

\subsection{Daylighting simulation}

The daylighting performance of the STB was conducted during several particular days of the year, namely the winter and summer solstice, and autumn and spring equinoxes.

Fig. 9 and Fig. 10 show the measured illuminances and the simulation output results from the winter solstice -21 st December - under cloudy skies, which is the most relevant sky condition to evaluate daylighting performance [32].

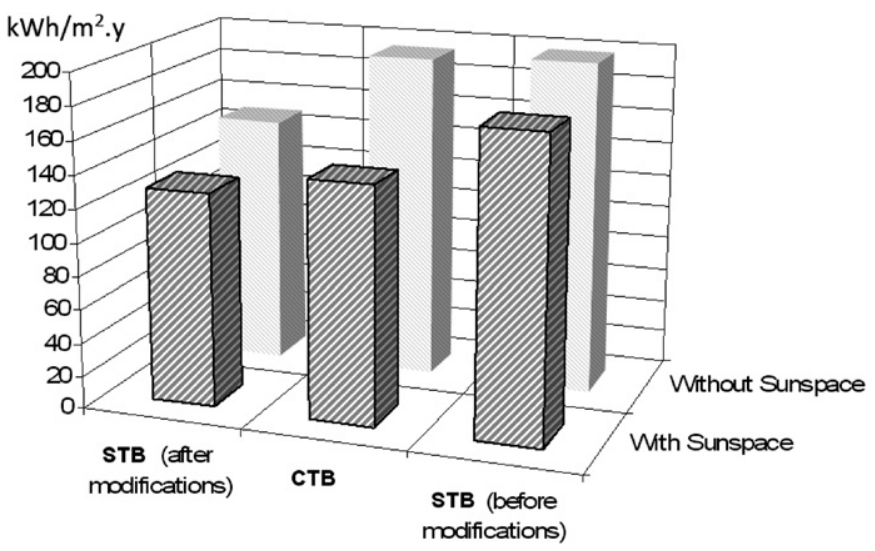

Fig. 8. Test buildings simulated energy consumption ( $\mathrm{kWh} / \mathrm{m}^{2}$.year). 


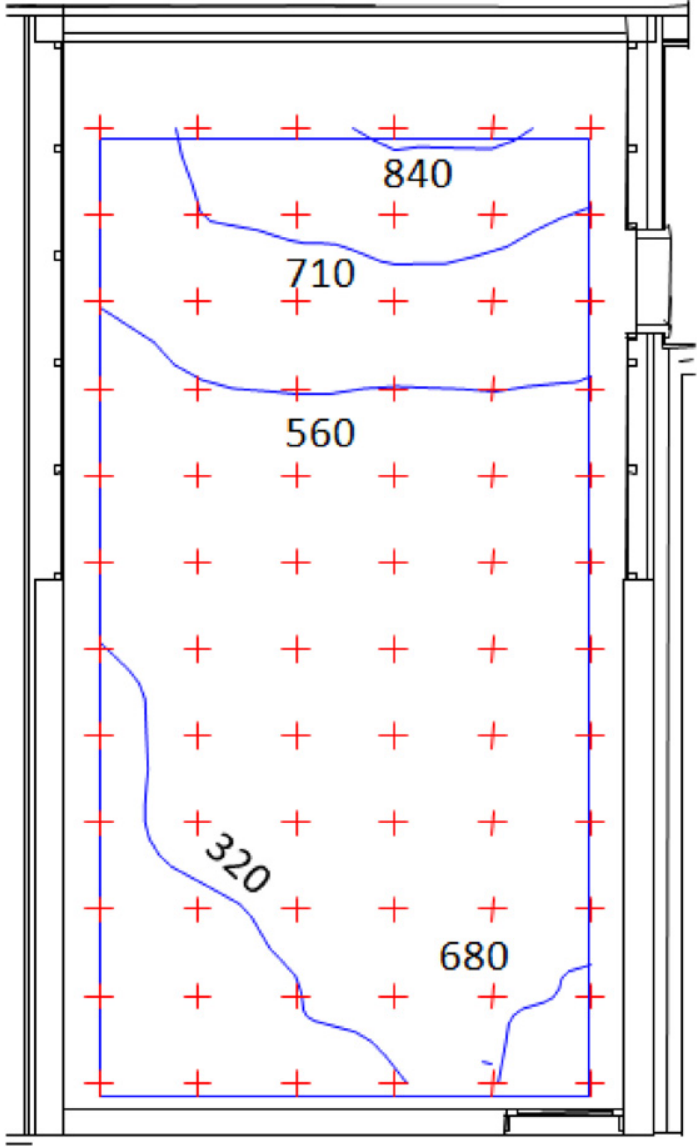

Fig. 9. Measured illuminance Isolines on winter solstice (lux).

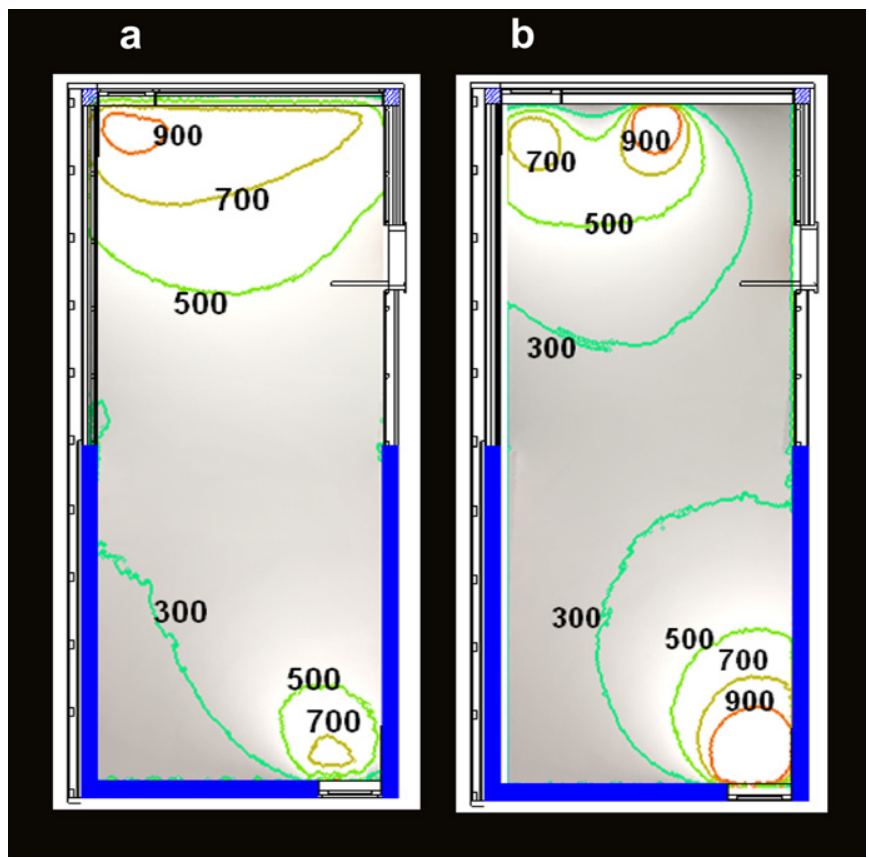

Fig. 10. Simulated illuminance Isolines on winter solstice (lux): a) original; b) reduced glazing.
From the perspective of daylight simulation evaluation, it was possible to observe a good correspondence between the measured and simulated values of illuminance. It was further verified that the STB had a good light distribution throughout the test building, and that the reduction of the natural lighting levels due to the modifications of the STB north façade was not significant.

\section{Conclusions}

In this study two models for energy performance and one for daylighting performance of the test buildings were calibrated with good accuracy, and a weather file was created for the city of Guimarães. This study paves the way for future studies with the recourse of simulation tools that can help to develop of new optimised solutions for this climate - temperate with hot and dry summer.

The comparison carried out between a Conventional Test Building - CTB - built in conformity with the traditional Portuguese heavyweight construction systems, and a Sustainable Test Building - STB - built according to a mixed-weight strategy and passive solar strategy showed that the use of Sustainable Construction Technologies and materials, with less embodied energy and of local availability, can lead to solutions with similar or superior energy performances than the conventional solutions employed in Portugal. Thus, the implementation of innovative solutions can be beneficial to the environment, resulting in the promotion of Sustainable Development.

\section{Acknowledgements}

This work was supported by ERDF funds through the Competitiveness Factors Operational Programme - COMPETE and National Funds through FCT - Foundation for Science and Technology [project number FCOMP-01-0124- FEDER-007189]. The author, Pedro Silva, was supported by FCT and DST, S.A. [grant number SFRH/BDE/15599/2006], which was co-financed by the Human Potential Operational Programme of the European Union POPH NSRF - Type 4.1 - Advanced Training, shared by the European Social Fund and national funds MCTES. Finally, a special thanks is addressed to Paulo Mendonça for all the effort and hard work committed to the design and construction of the test buildings used for this article.

\section{References}

[1] M.S. Todorovic, J.T. Kim, Buildings energy sustainability and health research via interdisciplinarity and harmony, Energy and Building 47 (2012) 12-19.

[2] Eurostat, Europe in Figures - Eurostat Yearbook 2010, European Union, 2010.

[3] European Commission, EU Energy Factsheet (June, 2011) Directorate-General for Energy.

[4] B. Poel, G. van Cruchten, C.A. Balaras, Energy performance assessment of existing dwellings, Energy and Building 39 (2007) 393-403.

[5] EPBD - European commission. Energy performance of buildings directive Recast. 2010/31/EU of the European parliament and of the council of 19 May 2010.

[6] S. Aggerholm, H. Erhorn, R. Hitchin, H. Erhorn-Kluttig, B. Poel, K.E. Thomsen, K.B. Wittchen, Cost Optimal Levels for Energy Performance Requirements, , In: Concerted Action for Energy Performance of Buildings, European Union, July, 2011.

[7] SCE -; Portuguese Energy Certification System. Ministry of Public Works, Transportation and Communications, Decree-Law $N^{\circ}$ 78/2006 of April 4, 2006.

[8] L. Ayea, T. Ngoa, R.H. Crawfordb, R. Gammampilaa, P. Mendisa, Life cycle greenhouse gas emissions and energy analysis of prefabricated reusable building modules, Energy and Building 47 (2012) 159-168.

[9] S. Denga, Y.J. Daia, R.Z. Wanga, T. Matsuurab, Y. Yasuib, Comparison study on performance of a hybrid solar-assisted $\mathrm{CO} 2$ heat pump, Applied Thermal Engineering 31 (2011) 3696-3705.

[10] J.C. Stephensa, J. Bielickib, G.M. Rand, Learning about carbon capture and storage: Changing stakeholder perceptions with expert information, Energy Procedia 1 (2009) 4655-4663.

[11] M.C. Peel, B.L. Finlayson, T.A. McMahon, Updated World map of the KöppenGeiger climate classification, Hydrology and Earth System Sciences 11 (2007) 1633-1644. 
[12] J. Littler, Test cells: do we need them? Building and Environment 28 (1993) 221-228.

[13] P. Wouters, L. Vandaele, P. Voit, N. Fisch, The use of outdoor test cells for thermal and solar building research within the PASSYS project, Energy and Building 28 (1993) 107-113.

[14] S. Jensen, Validation of building energy simulation programs: a methodology, Energy and Building 22 (1995) 133-144.

[15] E.M. Ryan, T.F. Sanquist, Validation of building energy modeling tools under idealized and realistic conditions, Energy and Building 47 (2012) 375-382.

[16] P.A. Strachan, L. Vandaele, Case studies of outdoor testing and analysis of building components, Building and Environment 43 (2008) 129-142.

[17] J.L.M. Hensen, R. Lamberts, Introduction to building performance simulation, in: J.L.M. Hensen, R. Lamberts (Eds.), Building Performance Simulation for Design and Operation, Spon Press, London, 2011, pp. 1-14.

[18] S. Goodhew, G. Griffiths, Sustainable earth walls to meet the building regulations, Energy and Building 37 (2005) 451-459.

[19] P. Silva. Thermal performance evaluation of non-conventional constructions through simulation in VisualDOE. M.Sc. Thesis. University of Minho, Guimarães, Portugal, 2006.

[20] P. Mendonça. Habitar sob uma Segunda Pele: Estratégias para a Redução do Impacto Ambiental de Construções Solares Passivas em Climas Temperados. PhD Thesis, Universidade do Minho. Guimarães, Portugal, 2005.

[21] P. Mendonça, L. Bragança, Energy optimization through thermal zoning - the outer skin, in: Proceedings of the Hhealthy Bbuildings-7th International Conference, School of Design and Environment, National University of Singapore, 2003.
[22] Green Design Tools, VisualDOE 3.0 Program Documentation, Eley Associates, San Francisco, 2001

[23] Desktop Radiance 2.0 BETA. User Manual, Marinsoft, inc. and Lawrence Berkeley National Laboratory, 2001.

[24] C. Barnaby, Weather data for building performance simulation, in: J.L.M. Hensen, R. Lamberts (Eds.), Building Performance Simulation for Design and Operation, Spon Press, London, 2011, pp. 37-55.

[25] ASHRAE Handbook - Fundamentals (I-P Edition), American Society of Heating, Refrigeration and Air-Conditioning Engineers, Inc., 2009.

[26] ISQ, Térmica Dos Edifícios, Instituto de Soldadura e Qualidade, Oeiras, 2000.

[27] J. Krieder, P.S. Curtiss, A. Rabl, Heating and Cooling of Buildings: Design for Efficiency, , In: Mechanical and Aerospace Engineering Series CRC Press, 2009.

[28] ASTM, Standard Practice for Determining Thermal Resistance of Building Envelope Components from the In-Situ Data. Standard C 1155-95, , In Annual Book of ASTM Standards, 04.11 (1999) West Conshohocken.

[29] J.-M. Mottard, A. Fissore, Thermal simulation of an attached sunspace and its experimental validation, Solar Energy 81 (2007) 305-315.

[30] P.O. Fanger, in: Robert E. Krieger (Ed.), Thermal Comfort, Publishing Company, Malabar, Finland, 1982.

[31] EN 12464 - 1Light and Lighting - Lighting of Work Places- Part 1: Indoor Work Places, The European Committee for Standardization, Brussels, Belgium, 2002.

[32] M.S. Rae, The IESNA Lighting Handbook, Reference \& Application, nineth ed. IESNA, New York, NY, 2000. 